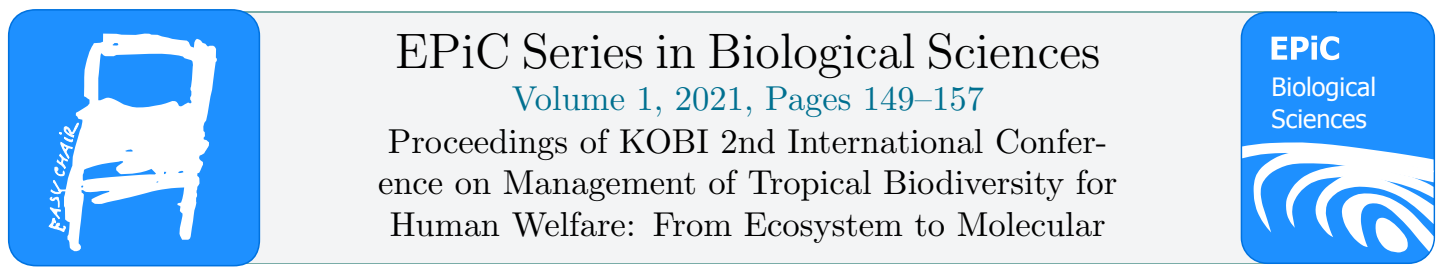

\title{
Description of Stomatal Sizes and Types from Several Shading and Ornamental Plants in Pontianak West Kalimantan
}

\author{
Dhea Vivin $\mathrm{K}^{1}$ and Entin Daningsih ${ }^{*}$ \\ ${ }^{1}$ Universitas Tanjungpura, Pontianak, Indonesia \\ entin.daningsihefkip.untan.ac.id
}

\begin{abstract}
Stomatal size is very important related to the transpiration rate. Stomatal types relate to the genetic relationship. This research aimed to describe the stomatal size and type from the shading and ornamental plants in Pontianak. The stomatal sizes and types were measured under $10 \times 10$ and $10 \times 40$ of magnification subsequently, equipped with a standardized micrometer. Of the 26 plants species, the longest stomata were found in Rhoe discolor $(74.44 \mu \mathrm{m})$ and the shortest in Mangifera indica L. $(15.65 \mu \mathrm{m})$ whilst the widest stomata were found in Rhoe discolor $(42.08 \mu \mathrm{m})$ and the narrowest was found in Morinda citrifolia L., Syzygium malaccense L., and Chlorophytum comosum with the width was only $9.71 \mu \mathrm{m}$. There were three stomatal types (paracytic, anomocytic, and anisocytic) that were found in 20 dicotyledon plants and four stomatal types (type 1, 2, 3, and 4) were found in six monocotyledon plants. The most common type was paracytic found in 11 dicotyledon plants. This stomatal size becomes the foundation to do further research related to the transpiration rate whereas stomatal types can indicate the closeness of the genetic relationship.
\end{abstract}

\section{Introduction}

Stomata is a part of the leaf that has a very important function for plants, namely for transpiration and plays a role in photosynthesis (Sumardi \& Pudjorianto, 1993). Stomata transpiration and photosynthesis are affected by the number and size of the stomata. If the number and the size of stomata are small, they will interfere with the process of transpiration and photosynthesis (Haryanti, 2010). Tambaru et al. (2013) explained that the size of the stomata is inversely proportional to the number of stomata on the leaves of the plant. If the size of the stomata is small, the number of stomata found on the leaves is high, whereas if the stomata size is large, the number of stomata on the leaves is low. Furthermore, Carlson et al. (2016) in their study of the arid region in South African bushes found that the number of stomata increased with the annual extreme temperature and would decrease during rain 
in the middle of the summer. When the number of stomata increases, the plants will adapt by reducing the size of the stomata. Likewise, in the Central Amazonia region, the number of stomata is inversely proportional to the size of the stomata. Where if the number of stomata is low then the size of the guard cell is large (Camargo dan Ricardo, 2011). In Makasar area (Tambaru et al., 2011) also showed there was a negative relationship between the number of stomata and the size of the stomata; however, this study did not show the types of stomata related to size or plant species.

The type of stomata in leaves varies greatly. Based on the stomata relationship with neighboring epidermal cells there are many types of stomata. Modification of stomata types can occur in species from various families. More than one type of stomata sometimes occurs together on the same organ. The stomata type not only has diagnostic value but is also used naturally as an indicator of taxonomic similarity, for example distinguishing 15 types of stomata in ferns, gymnosperms, and angiosperms based on their surface appearance (Fahn, 1991).

In most plants, the stomata are more on the lower surface of the leaves compared to the upper surface. This adaptation will minimize water loss that occurs faster through the stomata at the top of the sun-exposed leaf (Gardner et al., 1991; Hidayat, 1995). This is in accordance with the research of Hidayati (2009) stating that the amount of stomata density under the surface of the leaf is higher than that on the leaves in the types of shading plants. This finding is in line with the research by Istiqomah (2016), Christin (2016), and Tanugrah (2016), who stated that the number of stomata in the abaxial part (under surface) is higher than the adaxial (upper surface) part of the leaf.

There are several studies regarding the sizes and types of stomata in various regions. As Tambaru et al. (2011) showed four stomata types were obtained from seven tree species, namely parasitic (dominant), anisocytic, longitudinal, and anomocytic types that accompanied by two neighboring cells with stomata size categories which were less long, long (dominant) and very long. Furthermore, Rahayu et al. (2015) found that the parasitic stomata types from four species of the genus Alamanda with a category of long and very long. Istiqomah (2016), Christin (2016), and Tanugrah (2016) found the number of stomata and chlorophyll levels varies amongst the plants. However, the size and type of the stomata are not studied, therefore, the need for further research on the type and size of the stomata was needed. The total number of plants to be studied was 26 plant species. The purpose of this study was to analyze the size of the stomata associated with the types of stomata in plants in Pontianak City, West Kalimantan.

\section{Materials and Methods}

\subsection{Materials}

Olympus microscope was used with the magnification of $10 \times 10$ and 10x40 for stomatal sizes and types, subsequently. The microscope was equipped with an ocular and object micrometer that has been standardized. Microscope slides of stomata made from the replicate method originated from 26 plant species. A mobile camera was used to take the photos stomata size under microscope observation.

The sizes of stomata were categorized into length and width. The length categories were divided according to Agustini (1994). The categories were less long $(<20 \mu \mathrm{m})$, long $(20-25 \mu \mathrm{m})$, and very long $(>25 \mu \mathrm{m})$. The width was categorized into less wide $(<19.42 \mu \mathrm{m})$, wide $(19.42-38.84 \mu \mathrm{m})$, and very wide $(>38.84 \mu \mathrm{m})$. The stomata size was analyzed according to monocots and dicots plants. 


\subsection{Methods}

Stomatal Measurement. The method of stomatal measurement refers to the research conducted by Haryanti and Tetrinica (2009). The length and width of the stomata can be measured through the length and width of the stomatal guard cells (Savvides et al., 2011). Measuring stomata using objective and ocular micrometers were carried out from $10.00-12.00 \mathrm{am}$. The stomatal observation was from the upper and lower surface of the epidermis. This was conducted due to the maximal growth of stomatal size within that time. For each section of observation, three replications were carried out.

Stomatal measurements were carried out in two stages:

a. Micrometer Calibration: ocular micrometer was put on the ocular lens giving a picture of line score. Another object micrometer was then put in the object lens. The line coming out from the object micrometer was positioned in line together with the line of the ocular microscope (Agustini, 1994). The calibration value was calculated using the following formula:

The scale on the micrometer $=\frac{A}{B} \times 0,01 \mathrm{~mm} \times 1000 \mu \mathrm{m}$

in which $\mathrm{A}=\sum$ the scale on the object micrometer which coincides on the right side; $\mathrm{B}=\sum$ the scale of the ocular micrometer between two lines coinciding with the objective micrometer; $0,01=$ value each scale on the object micrometer in $\mathrm{mm}$; and $1000=$ conversion value from millimeters to micrometers. $(1 \mathrm{~mm}=1000$ micrometers)

b. Measuring Stomatal Length and Width: after the scale value of the ocular micrometer was known, the object micrometer was taken and replaced with the microscope slides of stomata to be measured. The ocular micrometer stayed in its original place. The magnification of the objective lens used for measurement must be the same as the lens used for calibration. The scale of the ocular lens was put on the position of the scale preserved slides so that the length and the width of stomata can be measured. Length and width were measured using the scale multiplied by calibration value. The standard errors were calculated for each length and width plant.

Determination of stomatal plant types. The observation of the stomata types was carried out using an Olympus microscope with $10 \times 40$ magnification so that the appearance of the type was clearer. The type of stomata observed refers to the study of Tambaru et al. (2011). The stomata types in dicotyledon plants were classified according to the arrangement of epidermal cells adjacent to the guard cell which refers to the explanation of Metcalfe \& Chalk (1950). Classification of the stomatal type was divided into six types, namely anomocytic (ranunculaceous), anisocytic (cruciferous), parasitic (rubiaceous), diacytic (caryophyllaceous), actinositic, and cyclocytic. Whereas in monocotyledon plants the types of stomata were classified into four types, namely type1, type 2, type 3, and type 4 (Stebbin and Kush, 1960).

Data analysis. The measurement of stomata was averaged and grouped into length (Agustini, 1994) and width categories. The stomata observation based on guard cell position was classified into stomatal types according to Metcalfe \& Chalk (1960) and Stebbin \& Kush (1960).

\section{Results and Discussion}

The observation of stomatal size was conducted for 26 plants of dicotyledons and monocotyledons. These plants function as shading or ornamental plants found in Pontianak city. The stomatal size included the length and width of the guard cells were conducted. The results of the study can be seen in Table 1 and Table 2. 


\begin{tabular}{|c|c|c|c|}
\hline Categories & Size $(\mu \mathrm{m})$ & $\begin{array}{c}\text { Standard } \\
\text { Error }\end{array}$ & Plants \\
\hline \multirow{4}{*}{ Less Long } & 16.73 & \pm 1.17 & 1. Syzygium oleana \\
\hline & 18.88 & \pm 0.54 & 2. Swietenia mahagoni King. \\
\hline & 15.65 & \pm 0.71 & 3. Mangifera indica $\mathrm{L}$. \\
\hline & 17.80 & \pm 1.62 & 4. Chlorophytum comosum \\
\hline \multirow{11}{*}{ Long } & 20.51 & \pm 1.07 & 1. Acacia mangium Willd. \\
\hline & 24.28 & \pm 2.80 & 2. Morinda citrifolia L. \\
\hline & 24.28 & \pm 1.14 & 3. Polyalthia longifolia Benth. \\
\hline & 21.04 & \pm 2.81 & 4. Syzygium malaccense L. \\
\hline & 22.66 & \pm 3.24 & 5. Samanea saman Merr. \\
\hline & 24.28 & \pm 2.80 & 6. Tabebuia aurea \\
\hline & 20.50 & \pm 1.94 & 7. Terminalia catappa $\mathrm{L}$. \\
\hline & 21.58 & \pm 0.85 & 8. Artocarpus heterophylla L. \\
\hline & 21.05 & \pm 2.17 & 9. Ruellia tuberosa $\mathrm{L}$. \\
\hline & 21.85 & \pm 2.17 & 10. Calathea lutea \\
\hline & 23.88 & \pm 1.84 & 11. Cordyline fruticose \\
\hline \multirow{11}{*}{$\begin{array}{l}\text { Very } \\
\text { Long }\end{array}$} & 26.98 & \pm 1.56 & 1. Pterocarpus indicus Willd. \\
\hline & 28.05 & \pm 1.77 & 2. Acalypha siamensis \\
\hline & 29.67 & \pm 2.05 & 3. Ixora williamsii \\
\hline & 25.90 & \pm 1.62 & 4. Alamanda cathartica \\
\hline & 28.73 & \pm 1.11 & 5. Bougainvillea spectabilis Willd. \\
\hline & 28.59 & \pm 1.10 & 6. Cassia surattensis Burm. \\
\hline & 35.61 & \pm 2.14 & 7. Mimusops elengi $\mathrm{L}$. \\
\hline & 36.68 & \pm 1.48 & 8. Aerva sanguinolenta \\
\hline & 38.03 & \pm 1.95 & 9. Canna indica \\
\hline & 74.44 & \pm 3.24 & 10. Rhoeo discolor \\
\hline & 72.31 & \pm 1.41 & 11.Hymenocallis littoralis Jacq. \\
\hline
\end{tabular}

Table 1. Stomatal Length Categories from 26 Plant Species in Pontianak

Eleven plant species were categorized into long $(20-25 \mu \mathrm{m})$ as well as very long $(>25 \mu \mathrm{m})$ stomata (Table 1), whereas only 4 plant species that were categorized into less long stomata. From 26 plant species, mostly plants have long and very long stomata. The variation of stomatal length could occur due to their genetic or environment. Some plants have no variation of stomatal sizes within their species. It can be shown by the number of standard error equal to zero. But in this research, there is no plant with a standard error equal to zero. The standard error more than zero indicated the plant stomatal length was various which mean in the same species stomatal length can be found in different size. According to Jordan et al. (2015), the stomatal size can adapt to its environment. According to Wolf et al. (1990) showed the stomatal size of potato was different when exposed to different temperatures. However, some plants did have stomatal size that does not change although exposed to the different environments. According to Gole et al. (2013) stomatal size was genetically inherited solely.

Plant with the highest stomatal length was found in Rhoe discolor $(74.44 \mu \mathrm{m})$ whilst the lowest was found in Mangifera indica L. $(15.65 \mu \mathrm{m})$. This stomatal length could indicate the size of stomatal pores function for water vapor density and gaseous exchange. The higher water vapor density in a plant the more transpiration occurs. However, Lawson \& Blatt (2014) found transpiration rate was not correlated with stomatal pores. But Xu \& Zhou (2008) showed that the water vapor density increased when the size of stomata improved during the day. 


\begin{tabular}{|c|c|c|c|}
\hline $\begin{array}{c}\text { Width } \\
\text { Categories }\end{array}$ & $\begin{array}{l}\text { Size } \\
(\mu \mathrm{m})\end{array}$ & $\begin{array}{c}\text { Standard } \\
\text { Error }\end{array}$ & Plants \\
\hline \multirow{8}{*}{ Less wide } & 18.34 & \pm 0.71 & 1. Pterocarpus indicus Willd. \\
\hline & 9.71 & \pm 0 & 2. Morinda citrifolia $\mathrm{L}$. \\
\hline & 15.11 & \pm 0.97 & 3. Acalypha siamensis \\
\hline & 18.34 & \pm 0.71 & 4. Polyalthia longifolia Benth. \\
\hline & 16.19 & \pm 0.81 & 5. Swietenia mahagoni King. \\
\hline & 14.57 & \pm 0 & 6. Alamanda cathartica \\
\hline & 14.57 & \pm 0 & 7. Artocarpus heterophylla $\mathrm{L}$. \\
\hline & 9.71 & \pm 0 & 8. Syzygium malaccense L. \\
\hline \multirow{11}{*}{ Less wide } & 12.95 & \pm 1.62 & 9. Samanea saman Merr. \\
\hline & 17.80 & \pm 1.62 & 10. Tabebuia aurea \\
\hline & 18.62 & \pm 1.31 & 11. Bougainvillea spectabilis Willd. \\
\hline & 11.33 & \pm 0.81 & 12. Syzygium oleana \\
\hline & 10.25 & \pm 0.54 & 13. Mangifera indica $\mathrm{L}$. \\
\hline & 18.34 & \pm 1.35 & 14. Mimusops elengi L. \\
\hline & 11.33 & \pm 0.81 & 15. Terminalia catappa $\mathrm{L}$. \\
\hline & 15.38 & \pm 2.40 & 16. Ruellia tuberosa $\mathrm{L}$. \\
\hline & 17 & \pm 1.08 & 17. Canna indica \\
\hline & 15.79 & \pm 0.63 & 18. Cordyline fruticose \\
\hline & 9.71 & \pm 0 & 19. Chlorophytum comosum \\
\hline \multirow{6}{*}{ Wide } & 21.04 & \pm 1.14 & 1. Ixora williamsii \\
\hline & 20.78 & \pm 0.70 & 2. Acacia mangium Willd. \\
\hline & 20.50 & \pm 1.08 & 3. Cassia surattensis Burm. \\
\hline & 21.04 & \pm 1.62 & 4. $\quad$ Calathea lutea \\
\hline & 29.94 & \pm 1.72 & 5. Aerva sanguinolenta \\
\hline & 23.20 & \pm 0.93 & 6. Hymenocallis littoralis Jacq. \\
\hline Very Wide & 42.08 & \pm 3.24 & 1. Rhoeo discolor \\
\hline
\end{tabular}

Table 2. Stomatal Width categories from 26 plant species in Pontianak

There were nineteen plants included in the less wide category. They were Morinda citrifolia L. (9.71 $\mu \mathrm{m})$, Syzygium malaccense L. $(9.71 \mu \mathrm{m})$, and Chlorophytum comosum $(9.71 \mu \mathrm{m})$ having the smallest wide. The opening of stomata will be determined by the size of length and width. So far, the measurement of size was reflected by the length only; Nonetheless, the opening of stomata is the function of the size of guard cell pores. The bigger pores the faster water vapor exchange. The pores were reflected not only the length but also the width of the stomata guard cell. Therefore, the width size only cannot determine the opening pores of stomata. In this research, the categories of less width must relate to the categories of length. In this research, Chlorophytum comosum was included less wide with the less long category. However, the other two Morinda citrifolia L. and Syzygium malaccense L. were included in less wide and long category. These differences will affect the opening size of the pores. The information of the stomatal size, therefore, needs to consider both the length and width of the stomata guard cell. To give more accurate information about the size of opening pores the length and the width should be calculated. In this research, the size of stomata was only described by the length and the width.

For those plants with the categories of wide and very wide should also be considered with the length size of stomata. Table 2 showed that the largest width was $42.08 \mu \mathrm{m}$ in the Rhoeo discolor. 


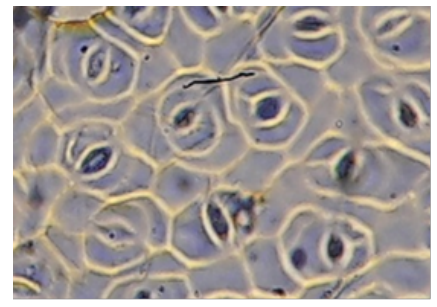

A

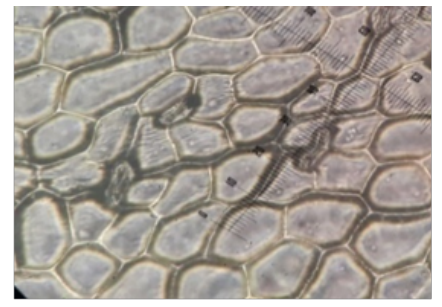

B

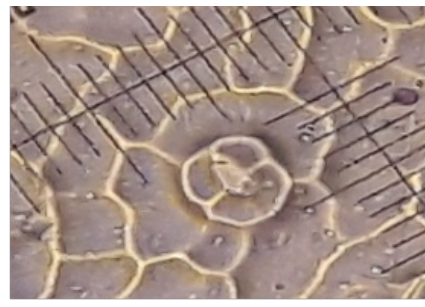

C

Figure 1: Three stomatal types of 6 in 20 dicotyledons plants in Pontianak: Paracytic (A), Anomocytic (B), Anisocytic (C)

The plants were included in 20 dicotyledons and 6 monocotyledons plants. According to Metcalfe and Chalk (1950), there were seven stomatal types usually found in dicotyledon plants. The difference in stomatal types depends upon how the position of epidermis cell surrounding the guard cells. Based on how the distribution of epidermis surrounding stomatal guards there were only found three stomatal types namely paracytic, anomocytic, and anisocytic (figure 1). In paracytic type, the stomata remain surrounded by two subsidiary or accessory cells which are parallel to the long axis of the pore and guard cells (Figure 1.A). In anomocytic type, the stomata remain surrounded by a limited number of subsidiary cells which are quite alike the remaining epidermal cells. The accessory or subsidiary cells are five in number (Figure 1.B). In anisocytic, stomata remain surrounded by three accessory or subsidiary cells of which one is distinctly smaller than the other two (Figure 1.C).

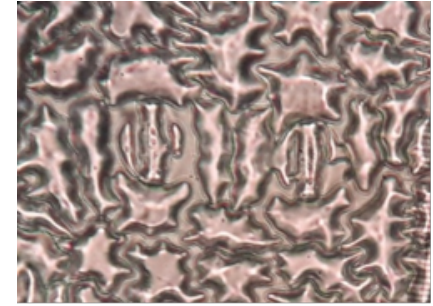

A

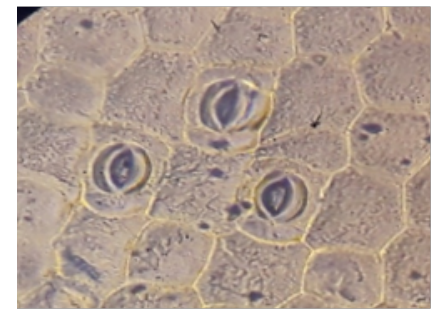

C

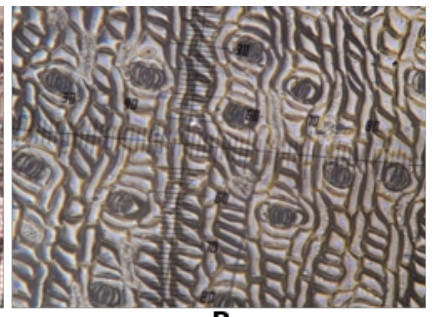

B

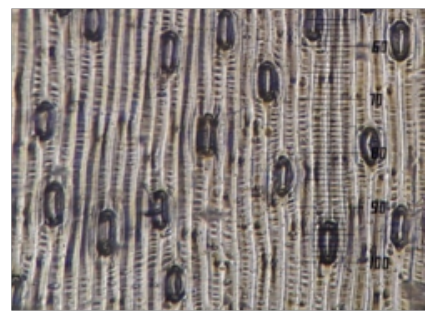

D

Figure 2: Four stomatal types of 6 monocotyledons plants in Pontianak: Type 1 (A), Type 2 (B), Type 3 (C), Type 4 (D)

According to Stebban and Kush (1960), there were four stomatal types found in monocotyledon plants. The difference in stomatal types depends upon the number of neighboring cells surrounding the stomatal guard cells. Based on the number of neighboring cells surrounding stomatal guard cells there were found four stomatal types namely type 1,2,3, and 4 . Type 1 was marked by a guard cell surrounded by four to six neighboring cells (Figure 2.A). Type 2 was marked by a guard cell surrounded by four to six neighboring cells, two of which are round-shaped, smaller, and located at the end of the 


\begin{tabular}{|c|c|c|c|}
\hline Class & $\begin{array}{l}\text { Type of } \\
\text { Stomata }\end{array}$ & Family & Plants \\
\hline \multirow{9}{*}{ Dicotyledons } & \multirow{9}{*}{ Parasytic } & Fabaceae & Pterocarpus indicus Willd. \\
\hline & & Rubiaceae & Morinda citrifolia $\mathrm{L}$ \\
\hline & & Euphorbiaceae & Acalypha siamensis \\
\hline & & Rubiaceae & Ixora williamsii \\
\hline & & Fabaceae & Acacia mangium Willd. \\
\hline & & Annonaceae & Polyalthia longifolia Benth. \\
\hline & & Meliaceae & Swietenia mahagoni King. \\
\hline & & Apocynaceae & Alamanda cathartica \\
\hline & & Moraceae & Artocarpus heterophylla L. \\
\hline \multirow{10}{*}{ Dicotyledons } & \multirow{2}{*}{ Parasitic } & Myrtaceae & Syzygium malaccense L. \\
\hline & & Fabaceae & Samanea saman Merr. \\
\hline & \multirow{5}{*}{ Anomocytic } & Bignoniaceae & Tabebuia aurea \\
\hline & & Fabaceae & Cassia surattensis Burm. \\
\hline & & Nyctaginaceae & $\begin{array}{l}\text { Bougainvillea spectabilis } \\
\text { Willd. }\end{array}$ \\
\hline & & Myrtaceae & Syzygium oleana \\
\hline & & Anacardiaceae & Mangifera indica $\mathrm{L}$. \\
\hline & \multirow{3}{*}{ Anisocytic } & Sapotaceae & Mimusops elengi L. \\
\hline & & Combretaceae & Terminalia catappa L. \\
\hline & & $\begin{array}{l}\text { Amaranthaceae } \\
\text { Acanthaceae }\end{array}$ & $\begin{array}{l}\text { Aerva sanguinolenta } \\
\text { Ruellia tuberosa L. }\end{array}$ \\
\hline \multirow{6}{*}{ Monocotyledons } & $\begin{array}{c}\text { Type } 1 \\
\text { Monocots } \\
\end{array}$ & Marantaceae & Calathea lutea \\
\hline & $\begin{array}{c}\text { Type } 2 \\
\text { Monocots }\end{array}$ & Cannaceae & Canna indica \\
\hline & \multirow{2}{*}{$\begin{array}{c}\text { Type } 3 \\
\text { Monocots }\end{array}$} & Commelinaceae & Rhoeo discolor \\
\hline & & Asparagaceae & Cordyline fruticose \\
\hline & \multirow{2}{*}{$\begin{array}{c}\text { Type } 4 \\
\text { Monocots }\end{array}$} & Asparagaceae & Chlorophytum comosum \\
\hline & & Amaryllidaceae & Hymenocallis littoralis Jacq. \\
\hline
\end{tabular}

(Figure 2.B). Type 3 was marked by a guard cell accompanied by two neighboring cells that are parallel to it on one side (Figure 2.C). Type 4 was marked by guard cells that do not join other additional cells (2.D).

Table 3. Stomatal types in Monocotyledon and Dicotyledon plants in Pontianak

Based on the observations of stomatal types, there were seven types found in 26 plants (Table 3 ). The types of dicotyledon plants were only three out of seven types mentioned by Metcalfe and Chalk (1950). Paracitic was the type mostly found in dicotyledon plants. There were eleven dicotyledon plants included in paracitic types. According to Gole et al. (2013), the stomatal types were more related to the taxonomic relationship. Further stomatal types that were found in Pontianak city were anemocytic and asocytic for five and four dicotyledon plants, subsequently. There were not found yet taxonomic relationships until the family level in anomocytic and asocytic. Each plant species came from a different family. However, in paracytic type, there were three plants (Pterocarpus indicus Willd., Acacia mangium Willd., Samanea saman Merr.) species included in one family (Fabaceae). Morinda citrifolia L. and Ixora williamsii were included in the same family (Rubiaceae). Whilst other plants were included in separated families. It could be the taxonomic relationship occur at the above level. Stomatal type was only one character of many others to justify classification. From six monocotyledons plants four stomatal types were found. Calathea lutea and Canna indica were included in type 1 and type 2, 
subsequently. Rhoeo discolor and Cordyline fruticose were included in type 3 whereas Chlorophytum comosum and Hymenocallis littoralis Jacq. were included in type 4. Fewer numbers of the plants found in type 1 to type 4 due to limited plant observation in monocotyledons found for shading and ornamental plants. Similar to dicotyledons plants, the stomatal types in monocotyledons were also related to the taxonomic relationship (Gole et al., 2013).

\section{Conclusions}

The stomatal length of 26 plants found in Pontianak city ranged from 15.65 to $71.44 \mu \mathrm{m}$. Stomatal width ranged from 9.71 to $42.08 \mu \mathrm{m}$. Both stomatal length and width should be calculated to get the pore area. There were seven stomatal types found in 26 plants in Pontianak city. Three stomatal types were found in dicotyledons (paracytic, anomocytic, and asosytic) whilst in monocotyledons, all types (type 1,2,3, and 4) were found. The stomatal types could be indicated taxonomic relationships.

\section{References}

Agustini, M. 1994. Identifikasi Ciri Arsitektur dan Kerapatan Stomata Dua Puluh Lima Jenis Pohon Suku Leguminosae untuk Elemen Lansekap Tepi Jalan. In Bahasa. Skripsi. Fakultas Pertanian, Institut Pertanian Bogor, Bogor.

Camargo MAB and Ricardo AM. 2011. Density, Size, and Distribution of Stomata in 35 Rainforest Tree Species in Central Amazonia. ACTA AMAZONICA. 41(2): 1-12.

Carlson JE, Cristopher AA, and Kent EH. 2016. Intraspecific Variation in Stomatal Traits, Leaf Traits, and Physiology Reflects Adaption along Aridity Gradients in A South African Shrub. Annals of Botany. 117: 195-207.

Christin D. 2016. Pembuatan Diorama Materi Pemanasan Global Kelas VII Berdasarkan Profil Kadar Klorofil dan Jumlah Stomata Tumbuh-Tumbuhan Di Jalan Panglima A'im dan Ya'm Sabran. In Bahasa. Skripsi. Fakultas Keguruan dan Ilmu Pendidikan, Universitas Tanjungpura, Pontianak.

Fahn A. 1991. Anatomi Tumbuhan Edisi ke-3. In Bahasa. Yogyakarta: Gadjah Mada University Press.

Gardner FPR, Brent P, and Roger LM. 1991. Fisiologi Tanaman Budidaya. In Bahasa. Jakarta: UI Press.

Gole AA, Ramugade MA, Bhagwat HR, Galkwad SS, Mohite PC, and Aparadh VT. 2013. Taxonomic Diversity of Stomata in Some Angiospermic Plants Satara Region India. International Research Journal of Pharmaceutical and Applied Sciences. 3(1): 52-55.

Haryanti S and Tetrinica M. 2009. Optimalisasi Pembukaan Porus Stomata Daun Kedelai (Glycine max (L) merril) pada Pagi Hari dan Sore. In Bahasa. BIOMA. 11(1): 18-23.

Haryanti S. 2010. Pengaruh Naungan yang Berbeda terhadap Jumlah Stomata dan Ukuran Porus Stomata Daun Zephyranthes rosea Lindl . In Bahasa. Buletin Anatomi dan Fisiologi, XVIII(1): 41-48.

Haryanti S. 2010. Jumlah dan Distribusi Stomata pada Daun Beberapa Spesies Tanaman Dikotil dan Monokotil. In Bahasa. Buletin Anatomi dan Fisiologi, XVIII(2): 21-28.

Hidayat EB. 1995. Dasar-Dasar Struktur dan Perkembangan Tumbuhan. In Bahasa. Bandung: ITB.

Hidayati SR. 2009. Analisis Karakteristik Stomata, Kadar Klorofil dan Kandungan Logam Berat Pada Daun Pohon Pelindung Jalan Kawasan Lumpur Porong Sidoarjo. In Bahasa. Skripsi. Fakultas Sains dan Teknologi, Universitas Islam Negeri Malang, Malang.

Istiqomah G. 2016. Pembuatan Multimedia Interaktif Anatomi Daun Kelas XI SMA Berdasarkan Analisis Jumlah Stomata dan Kadar Klorofil Tumbuhan di Jalan Tanjungpura dan Imam Bonjol. In Bahasa. Skripsi. Fakultas Keguruan dan Ilmu Pendidikan, Universitas Tanjungpura, Pontianak. 
Rahayu P, Ainur R, and Muizzudin. 2015. Perbedaan Anatomi Jaringan Stomata Berbagai Daun Genus Allamanda. In Bahasa. Prosiding Seminar Nasional Pendidikan Biologi. Universitas Muhammadiah, Malang.

Savvides A, Fanourakis D, and Leveren VW. 2011. Co-ordination of Hydraulic and Stomatal Conductances Across Light Qualities in Cucumber Leaves. Jurnal Experiment Botanical. 25: 11351143.

Tambaru E, Samuel AP, Sanusi D, and Anwar U. 2011. Karakter Morfologi dan Tipe Stomata Daun Beberapa Jenis Pohon Penghijauan Hutan Kota di Kota Makassar. In Bahasa. Jurnal Program Pascasarjana Universitas Hasanuddin Makassar. Retrieved from http://pasca.unhas.ac.id/jurnal/files/3d418deec0370edfa5c12def13aa68da.pdf.

Tambaru E, Andi IL, and Sri S. 2013. Peranan Morfologi dan Tipe Stomata Daun dalam Mengabsorpsi Karbon Dioksida pada Pohon Hutan Kota UNHAS Makassar. In Bahasa. Simposium Nasional Kimia Bahan Alam, XXI, 12-17.

Tanugrah N. 2016. Pembuatan Komik Pencemaran Udara Kelas VII SMP Berdasarkan Analisis Jumlah Stomata dan Kadar Klorofil Tumbuhan di Sepanjang Jalan Ahmad Yani. In Bahasa. Skripsi. Fakultas Keguruan dan Ilmu Pendidikan, Universitas Tanjungpura, Pontianak.

$\mathrm{Xu} \mathrm{Z}$ and Zhou G. 2008. Responses of leaf stomatal density to water status and its relationship with photosynthesis in a grass. Journal of Experimental Botany. 59(12): 3317-3325. 